\title{
Responses of Hydroponically Grown Common Bean Fed with Nitrogen-free Nutrient Solution to Root Inoculation with $\mathbf{N}_{2}$-fixing Bacteria
}

\author{
Charis-Konstantina Kontopoulou, Sofia Giagkou, Efthalia Stathi, \\ and Dimitrios Savvas ${ }^{1}$ \\ Agricultural University of Athens, Department of Crop Science, Laboratory \\ of Vegetable Crops, Iera Odos 75, 11855 Athens, Greece
}

Pietro P.M. Iannetta

The James Hutton Institute, Invergowrie, Dundee DD2 5DA, Scotland, U.K.

Additional index words. nutrient uptake, Phaseolus, soilless culture, symbiotic $\mathrm{N}_{2}$ fixation, pumice

\begin{abstract}
To date, few attempts have been made to assess the impact of Rhizobium inoculation on $\mathrm{N}_{2}$ fixation and plant yield in soilless cultivations of common bean. In the present study, common bean ( $P$. vulgaris $L$.) grown on an inert medium (pumice) was inoculated with either Rhizobium tropici CIAT899 or a commercial product containing a mix of $\mathrm{N}_{2}$-fixing bacteria, specifically rhizobia, and Azotobacter sp. The plants treated with both inoculants were supplied with nitrogen (N)-free $(0 \% \mathrm{~N})$ nutrient solution (NS) throughout the cropping period. A third treatment with non-inoculated plants, which were supplied with a standard $(100 \% \mathrm{~N}) \mathrm{NS}$ was applied as a control. Inoculation with $R$. tropici significantly increased the total number of root nodules ( 80 nodules per plant on average) in comparison with the other two treatments (nine nodules per plant on average). The supply of $\mathrm{N}$-free NS restricted markedly both total plant biomass and pod yield, whereas the inoculation with $R$. tropici mitigated this effect. The aboveground tissues of plants fed with $\mathbf{N}$-free NS contained appreciably less $N$ than those fed with standard solution when they were inoculated with the commercial inoculant $\left(1.7 \mathrm{vs} .29 \mathrm{mg} \cdot \mathrm{g}^{-1} \mathrm{dry}\right.$ weight, respectively). The shoot total $N$ concentration 45,65 , and 90 days after transplanting $\left(32,31\right.$, and $29 \mathrm{mg} \cdot \mathrm{g}^{-1}$ dry weight, respectively) was not reduced by the supply of $\mathrm{N}$-free NS when the plants were inoculated with $R$. tropici. This finding indicates that, at least from the first sampling date onward, the tissue $N$ level was not a limiting factor for growth and yield in plants inoculated with $R$. tropici. The supply of $\mathrm{N}$-free NS restricted appreciably the potassium $(\mathrm{K})$, magnesium $(\mathrm{Mg})$, and zinc $(\mathrm{Zn})$ levels in the aboveground plant biomass, regardless of inoculation treatment. The impaired growth and yield in plants fed with N-free NS and inoculated with $R$. tropici is ascribed to both a N shortage at early growth stages and a reduced $\mathrm{K}^{+}$uptake aimed at electrochemically balancing the anion-to-cation uptake ratio under conditions of no external $\mathrm{NO}_{3}{ }^{-}$supply.
\end{abstract}

Root inoculation of legumes with efficient nodulating bacteria of the genus Rhizobium aims to enhance biological $\mathrm{N}$ fixation and increase crop yield and quality. Legume inoculation with $\mathrm{N}_{2}$-fixing bacteria is an old

\footnotetext{
Received for publication 24 Nov. 2014. Accepted for publication $25 \mathrm{Jan} .2015$.

This work was supported by the European Commission within the project "Legume-supported cropping systems for Europe-LEGUME FUTURES" (grant agreement no. 245216 CP-FP), which was carried out under the EFP7 Cooperation Theme "Food, Fisheries and Biotechnologies." P.P.M. Iannetta is also supported by the Scottish Government.

We thank Dr. Jean-Jacques Drevon (INRA) for providing the $R$. tropici CIAT899 and Prof. E.K. James, Laura Lopez (The James Hutton Institute, U.K.), and Prof. Peter Young (Uni. York, U.K.) for their support and guidance with the isolation and identification of nodule bacteria.

${ }^{1}$ To whom reprint requests should be addressed; e-maildsavvas@aua.gr.
}

practice in agriculture, because Rhizobium inoculants have been used since the 19th century (Catroux et al., 2001; Stephens and Rask, 2000)

Biological $\mathrm{N}$ fixation by common bean $(P$. vulgaris L.) in the field is often low compared with that of other legumes (Remans et al., 2008). Nevertheless, several investigators showed that rhizobial inoculation of common bean can enhance root nodulation and yield (Graham, 1981; Hardarson, 1993; Thies et al., 1991). Older studies (Singleton and Tavares, 1986) have indicated many factors that may limit the efficacy of rhizobial inoculation and one of the main limiting factors is the presence of highly competitive indigenous Rhizobium populations in the soil (Segovia et al., 1991; Thies et al., 1991). Nevertheless, very little research work has adequately addressed the impact of Rhizobium inoculation on $\mathrm{N}_{2}$ fixation and yield performance in soilless cultivation of common bean.
Jebara et al. (2001) inoculated five common bean lines grown in two hydroponic systems (gravel in pots and aerated nutrient solution in bottles) with either Rhizobium tropici CIAT899 or native rhizobia from Tunesia using both saline and non-saline nutrient solutions. This research revealed that strain $\times$ line interactions should be considered for selecting the legume most adapted to salinity and that the aerated solution system is efficient for selecting highly efficient rhizobial symbioses. In another study, Zaman-Allah et al. (2007) investigated the effect of different rhizobial strains and phosphorus (P) supply in bean crops grown in a hydroponic system and found that inoculation with suitable rhizobia with a supply of additional $\mathrm{P}$ can improve symbiotic $\mathrm{N}_{2}$ fixation and yield in common bean. Nevertheless, to our best knowledge, the effects of rhizobia inoculation on common bean grown in N-free soilless media without $\mathrm{N}$ supply have not been reported in the international peer-reviewed literature to date. Soilless cropping systems often start with a "microbiological vacuum," lacking a diverse and competitive microflora (Postma et al., 2008), and thus competitiveness from indigenous microorganisms is not expected when inoculating soilless bean crops with rhizobia. Consequently, rhizobial inoculation in soilless bean crops may be more effective than in soil-grown crops in terms of both nodulation and yield.

In the present article, common bean grown hydroponically on pumice was inoculated with Rhizobium tropici strain CIAT899 or a commercial inoculum containing a mixture of rhizobia sp. and Azotobacter sp. The aim of this research was to compare the nodulation efficiency of these inoculants and to test whether biological $\mathrm{N}_{2}$ fixation is capable of covering the plant $\mathrm{N}$ requirements of common bean grown hydroponically when no inorganic $\mathrm{N}$ is provided through nutrient solution to the plants. The Rhizobium tropici strain CIAT899 was selected because previous research proved its efficiency in nodulating roots of common bean in soil-based production systems (Martinez-Romero et al., 1991). The commercial mix was selected because previous reports highlighted the potential of inoculating legumes with a combination of rhizobia and Azotobacter (Rodelas et al., 1999). Polymerase chain reaction (PCR)-sequencing analysis was used to test whether the applied inoculants successfully colonized the roots of common bean. Furthermore, root nodulation, plant biomass production, pod yield, $\mathrm{N}$ status in roots and shoot, and tissue nutrient concentrations were determined to test the impact of inoculation on growth, yield, and plant nutrient status in the hydroponically grown common bean plants.

\section{Materials and Methods}

Plant material and growth conditions. The experiment was conducted in a glasshouse at the Agricultural University of Athens (Greece) from 18 Oct. 2011 (date of sowing) to 27 Jan. 2012. Common beans (Phaseolus vulgaris L., cv. Contender) were 
sown in seedling trays filled with pumice granules ( 0 to $8 \mathrm{~mm}$ diameter) and placed in a temperature-controlled $\left(23\right.$ to $\left.26{ }^{\circ} \mathrm{C}\right)$ incubation chamber. The seedlings were transplanted to 12 closed-loop hydroponic circuits (experimental plots) $15 \mathrm{~d}$ after sowing, when they were at the two-cotyledon stage. Each loop was isolated and supplied with a separate NS. Each circuit comprised one channel (3.0 $\times$ $0.2 \times 0.3 \mathrm{~m}$, length $\times$ width $\times$ height $)$, which accommodated three bags $(1 \times 0.2 \times 0.2 \mathrm{~m}$, length $\times$ width $\times$ height) filled with pumice. Four seedlings were planted in each bag and this resulted in 12 plants per circuit. Three treatments (described in more detail below) were applied in a randomized complete block experimental design with four plots (replicates) per treatment.

Immediately after transplanting, seedlings in two of the three treatments were inoculated either with a liquid culture (10 mL/plant) containing Rhizobium tropici, strain CIAT899 ( $10^{9}$ colony-forming units $/ \mathrm{mL}$ ) or with a commercial product. The $R$. tropici inoculum was provided by Dr. Jean-Jacques Drevon (INRA, France). The commercial product contained a mix of $\mathrm{N}_{2}$-fixing bacteria, specifically rhizobia and Azotobacter sp. according to the information provided by the manufacturer on the product label (AzoRiz; Humofert, Athens, Greece). These applications were repeated after $6 \mathrm{~d}$. In both cases, the total $\mathrm{N}$ concentration in the fresh NS supplied to the plants to compensate for plant uptake was adjusted to zero level [denoted as "N-free $\mathrm{NS}(0 \% \mathrm{~N})+R$. tropici" and " $\mathrm{N}$-free NS $(0 \% \mathrm{~N})+$ com. mix"]. The concentrations of macronutrients (mM) in the $\mathrm{N}$-free NS were: $\mathrm{K}^{+} 5.00, \mathrm{Ca}^{2+} 2.50, \mathrm{Mg}^{2+} 1.20, \mathrm{NO}_{3}{ }^{-}$ $0.00, \mathrm{NH}_{4}^{+} 0.00, \mathrm{SO}_{4}{ }^{2-} 7.20, \mathrm{H}_{2} \mathrm{PO}_{4}^{-}$1.80. In the third treatment, the seedlings were not inoculated, and the total $\mathrm{N}$ concentration in the NS was adjusted to a standard level for green bean grown hydroponically (standard nutrient solution henceforth denoted as SNS, $100 \% \mathrm{~N}$, or control treatment). The composition of the SNS is based on an already published recipe for the hydroponic cultivation of common bean in Mediterranean greenhouses (Savvas et al., 2013) with the following macronutrient concentrations (mM): $\mathrm{K}^{+}$5.00, $\mathrm{Ca}^{2+}$ 2.50, $\mathrm{Mg}^{2+} 1.20, \mathrm{NO}_{3}^{-}$10.00, $\mathrm{NH}_{4}^{+} 1.50, \mathrm{SO}_{4}{ }^{2-} 2.60, \mathrm{H}_{2} \mathrm{PO}_{4}^{-}$1.20. The concentrations of micronutrients, i.e., iron, manganese, $\mathrm{Zn}$, copper, boron, and molybdenum, in both the SNS and the N-free NS were $12,6,4,0.5,20$, and $0.5 \mu \mathrm{m}$, respectively. The seedlings within each circuit were automatically supplied with NS from a dedicated "supplycistern" (i.e., a constant NS level was maintained using a floater) through a drip irrigation system. The level of NS in the supply-cistern was fed by a "replenishment tank" positioned above it, which contained either SNS or Nfree NS, depending on the treatment. Also, and for all treatments, the $\mathrm{pH}$ of the NS was adjusted daily to 5.6 to 5.7 by adding appropriate amounts of phosphoric acid.

Yield, growth measurements, and mineral composition. Fresh and dry aboveground biomass was recorded 45, 65, and $90 \mathrm{~d}$ after transplanting (DAT) by sampling two randomly selected plants per experimental plot on each sampling date. The roots of the plants collected on the mentioned dates were rinsed with water, blotted dry on filter paper, and the number of nodules per plant was recorded. Subsamples of the crushed dried aboveground plant biomass were powdered using a ball mill and passed through a 40-mesh sieve. Total $\mathrm{N}$ was determined using an automated Dumas procedure on a Carlo Erba NA 1500 elemental analyzer (Erba Science, U.K.). Mineral nutrients [K, P, magnesium $(\mathrm{Mg}), \mathrm{Zn}]$ were assayed after ashing dried plant biomass samples in a muffle furnace at $550{ }^{\circ} \mathrm{C}$ for $5 \mathrm{~h}$ and extraction of the ash using $1 \mathrm{~N} \mathrm{HCl}$. The obtained liquid extract was used to measure $\mathrm{K}$ through flame photometry, $\mathrm{P}$ colorimetrically as phosphomolybdate blue complex at $880 \mathrm{~nm}$ using a spectrophotometer (Eaton et al., 1995) and $\mathrm{Mg}$ and $\mathrm{Zn}$ by atomic absorption spectrophotometry. Green pods were harvested when they reached marketable size (over $23 \mathrm{~cm}$ ) to estimate total number of pods/plant and total yield ( $\mathrm{kg} / \mathrm{plant})$. Pod dry weights per plant were determined by drying representative samples of fresh green pods at $65^{\circ} \mathrm{C}$ until their mass was stabilized to a constant level.

Root nodule bacteria isolation and identification of rhizobial types. Frozen $\left(-80{ }^{\circ} \mathrm{C}\right)$ clean healthy root nodules were surface-sterilized $[2.5 \%(\mathrm{v} / \mathrm{v}) \mathrm{NaClO}, 30 \mathrm{~s}$, and rinsed three times in sterile distilled water] and placed on sterile yeast mannitol agar medium (YM; Vincent, 1970) plus congo-red dye $[0.0025 \%(\mathrm{w} / \mathrm{v})]$ contained within a petri dish. The nodule was crushed using sterile tweezers and the exudate spread over the agar surface before incubation $\left(28^{\circ} \mathrm{C}, 24\right.$ to $\left.48 \mathrm{~h}\right)$. Single colonies were reisolated by streaking onto a fresh YM-agar plate and prepared for long-term storage by culturing overnight in $3 \mathrm{~mL}$ tryptone-yeast media (TY; Beringer, 1974). Equal volumes $(0.75 \mathrm{~mL})$ of the culture and $50 \%(\mathrm{v} / \mathrm{v})$ sterile glycerol were mixed well before freezing in liquid $\mathrm{N}$ and storage at $-80^{\circ} \mathrm{C}$.

Isolates were cultured on liquid TY media for $24 \mathrm{~h}$ and at log-phase $4 \mathrm{~mL}$ was pelleted by centrifugation and the pellet re-suspended in TE buffer $(400 \mu \mathrm{L})$ containing greater than 800 $\mu \mathrm{m} \cdot \mathrm{mL}^{-1}$ proteinase-K (Sigma \#P4850; Signma, Poole, U.K.). After incubation $\left(37{ }^{\circ} \mathrm{C}, 1 \mathrm{~h}\right)$, an equal volume of phenol:chloroform:isoamyl alcohol [25:24:1 (v/v/v); Sigma \#P2069] was added and the mixture vortexed $(1 \mathrm{~min})$ and centrifuged. The aqueous phase $(200 \mu \mathrm{L})$ was recovered and combined with $10 \%(\mathrm{v} / \mathrm{v}) 3 \mathrm{M}$ sodium acetate $(\mathrm{NaOAc} ; \mathrm{pH} 5.2)$ and a $3 \times$ volume of chilled isopropanol (Sigma \#I9030). The DNA was precipitated by incubation $\left(-80^{\circ} \mathrm{C}, 15 \mathrm{~min}\right.$, or $-20^{\circ} \mathrm{C}$, overnight), pelleted by centrifugation, washed $[200 \mu \mathrm{L} / 70 \%$ (v/v) ethanol], re-centrifuging ( $2 \mathrm{~min})$, and dried $\left(37^{\circ} \mathrm{C}, 15 \mathrm{~min}\right)$ after removal of the supernatant. The DNA pellets were re-suspended in TE buffer $(25 \mu \mathrm{L})$. All centrifugation steps were performed at $14,000 \mathrm{rpm}$ and at $4{ }^{\circ} \mathrm{C}$.

A portion of the $16 \mathrm{~S}$ ribosomal RNA gene was amplified using the primers Bac $27 \mathrm{~F}$ (Lane, 1991) and Univ1492R (Jiang et al.,
2006), according to the manufacturer's recommendations (Promega \#M3175; Promega, Southampton, U.K.) using the following thermal profile: denaturation at $95{ }^{\circ} \mathrm{C}, 2 \mathrm{~min} ; 35$ cycles of $94{ }^{\circ} \mathrm{C} 30 \mathrm{~s}, 52^{\circ} \mathrm{C} 1 \mathrm{~min}, 72^{\circ} \mathrm{C} 1 \mathrm{~min}$, and $72{ }^{\circ} \mathrm{C}$ for $5 \mathrm{~min}$ (using a G-Storm GS1 thermal cycler; GRI Ltd., Braintree, U.K.). PCR products $(\approx 1400 \mathrm{bp}$ ) were purified using QIAquick Spin columns (Qiagen, Inc., Chatsworth, CA) and sequenced (ABI3730 DNA analyzer with a $36 \mathrm{~cm} \times 48$-cm capillary array; Applied Biosystems, by Life Technologies, Paisley, U.K.) using the internal-primer 519R (Lane et al., 1985). The resultant sequences were edited (BioEdit Sequence Alignment Editor Version 7.2; (C) Tom Hall, Ibis Biosciences, Carlsbad, CA) and screened against nucleotide databases using Basic Local Alignment Search Tool (BLASTN, National Center for Biotechnology Information, $\mathrm{Na}$ tional Library of Medicine, Bethesda, MD; Altschul et al., 1997) on the National Center for Biotechnology Information web site.

Statistical analysis. All data were statistically evaluated by applying analysis of variance using the STATISTICA Version 9.0 software package (StatSoft Inc. 2010, Tulsa, $\mathrm{OK})$. Duncan's multiple-range test was performed on each of the significant $(P<0.05)$ variables measured. Standard errors are displayed in graphs to depict statistical significance of the differences between treatment means.

\section{Results and Discussion}

PCR sequencing. PCR-sequencing analysis revealed the presence of $R$. tropici in all tested plants inoculated with this $\mathrm{N}_{2}$-fixing bacterium, whereas no $R$. tropici could be isolated in plant roots originating from the other two treatments (Table 1). This result confirms the successful inoculation of $P$. vulgaris plants with $R$. tropici in the relevant treatment and is in agreement with previous reports pointing to a high efficiency of $R$. tropici in nodulating common bean (Hungria et al., 2000, 2003; Mostasso et al., 2002). However, from the nodules of plants inoculated with the commercial mix, no $R$. tropici or Azotobacter species could be isolated. This finding indicates that either the inoculation technique used to apply the commercial mix failed or the $\mathrm{N}_{2}$-fixing species included in this commercial mix are incapable of colonizing the roots of common bean and form symbiotic associations. Furthermore, the Agrobacterium radiobacter $\mathrm{K} 84$ strain was isolated in plant roots from all treatments, including the control in which plants were not inoculated with any $\mathrm{N}_{2}$-fixing bacteria, which indicates that this microorganism does not originate from the inoculation treatments. Because the growing medium (pumice) used to grow bean plants in the present experiment is considered chemically and biologically inert (Postma et al., 2008), A. radiobacter either was present in the seeds of the bean or had been introduced from atmospheric deposition.

Nodulation. Inoculation with the $R$. tropici strain CIAT899 enhanced nodulation compared with both non-inoculation and inoculation 
Table 1. Polymerase chain reaction-sequencing analysis of root nodule bacteria isolated from a hydroponic crop of common bean inoculated with either $R$. tropici CIAT 899 or a commercial mix containing various rhizobia and Azotobacter sp. strains or non-inoculated. ${ }^{\mathrm{z}}$

\begin{tabular}{|c|c|c|c|}
\hline Treatment & BlastN results & Percent similarity & Rhizobia/Agro-bacterium + \\
\hline $100 \% \mathrm{~N}$ & A. radiobacter strain K84 $16 \mathrm{~S}$ ribosomal RNA, complete sequence & 99 & + \\
\hline $0 \% \mathrm{~N}+$ R. tropici & $\begin{array}{l}\text { Rhizobium tropici CIAT } 899 \text { strain USDA } 903016 \text { S ribosomal RNA, } \\
\text { partial sequence/A. radiobacter strain K84 16S ribosomal RNA, } \\
\text { complete sequence }\end{array}$ & 99 & + \\
\hline $0 \% \mathrm{~N}+$ commercial mix & A. radiobacter strain K84 16S ribosomal RNA, complete sequence & 99 & + \\
\hline
\end{tabular}

${ }^{\mathrm{z}}$ The inoculated plants were supplied with $\mathrm{N}$-free nutrient solution, whereas the non-inoculated plants were fed with a nutrient solution containing $100 \%$ of the standard recommended nitrogen $(\mathrm{N})$ level.

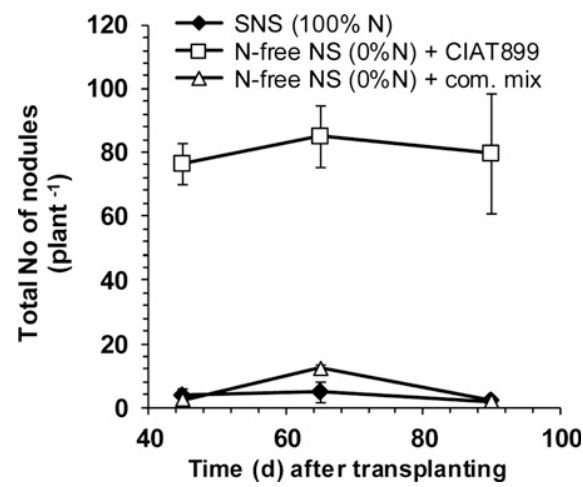

Fig. 1. Root nodulation in a hydroponic crop of common bean inoculated either with $R$. tropici CIAT 899 or with a commercial mix containing various rhizobia and Azotobacter sp. strains or non-inoculated. The inoculated plants were supplied with nitrogen $(\mathrm{N})$-free nutrient solution, whereas the non-inoculated plants were fed with a nutrient solution containing $100 \%$ of the standard recommended $\mathrm{N}$ level. SNS = standard nutrient solution. Vertical bars depict $\pm \operatorname{SES}(n=4)$.

with the commercial mix (Fig. 1). The total number of nodules per plant in the treatment inoculated with $R$. tropici was significantly higher ( 80 nodules per plant, average calculated across all samplings dates) in comparison not only with that recorded in non-inoculated plants (four nodules per plant, average calculated across all samplings dates), but also with the plants inoculated with the commercial mix (six nodules per plant, average calculated across all samplings dates). Previous studies (e.g., Thies et al., 1991; Zaman-Allah et al., 2007) also reported an increase in total number of nodules in legume plants inoculated with $R$. tropici. According to Singleton and Tavares (1986), a significant increase in nodule number did not always result in a $\mathrm{N}_{2}$-fixation increase, but only when the number of nodules in the inoculated plants was at least 2.5 times higher than in the non-inoculated controls. However, the number of nodules in plants inoculated with $R$. tropici increased to a much higher order of magnitude than 2.5 -fold in the present study. Thus, it is reasonable to assume that inoculation with $R$. tropici CIAT899 had a positive impact on biological $\mathrm{N}_{2}$ fixation as well. Nodulation in the plants supplied with $\mathrm{N}$-free NS and inoculated with the commercial mix also increased compared with the noninoculated treatment, but a significant difference was found only in one of the three sampling dates (12 vs. five nodules per plant, 65 DAT). As reported by Mhamdi et al. (2005), inoculation of $P$. vulgaris plants grown on

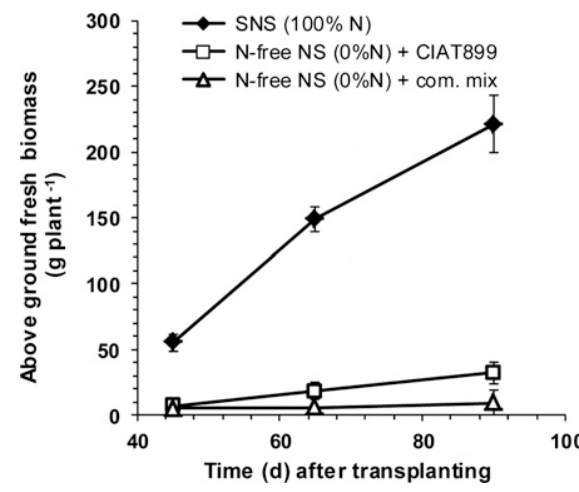

Fig. 2. Aboveground fresh plant biomass in a hydroponic crop of common bean inoculated either with $R$. tropici CIAT 899 or with a commercial mix containing various rhizobia and Azotobacter sp. strains or non-inoculated. The inoculated plants were supplied with nitrogen $(\mathrm{N})$-free nutrient solution, whereas the non-inoculated plants were fed with a nutrient solution containing $100 \%$ of the standard recommended $\mathrm{N}$ level. SNS = standard nutrient solution. Vertical bars depict $\pm \operatorname{SES}(n=4)$.

sterile gravel with Agrobacterium strains had no effect on the total number of root nodules. In the present study, only $A$. radiobacter but no $\mathrm{N}_{2}$-fixing bacteria were isolated from the roots of plants inoculated with the commercial mix. Thus, it seems that, in plants inoculated with the commercial mix, the weak increase in the number of nodules per plant was the result of $\mathrm{N}$ starvation, which is known to stimulate nodulation (Gan et al., 2004; Li et al., 2009) rather than the result of microorganisms included in the commercial mix.

Tissue nitrogen status. The establishment of an efficient symbiosis in bean plants inoculated with the $R$. tropici strain CIAT899 is further confirmed by the total $\mathrm{N}$ concentrations measured in the aboveground tissues of plants inoculated with $R$. tropici. As shown in Figure 2, the total $\mathrm{N}$ concentrations in the shoot of plants fed with an N-free NS and inoculated with $R$. tropici were not lower than in the non-inoculated plants fed with standard NS $(100 \% \mathrm{~N})$, at least from Day 45 after transplanting and onward. Especially 65 DAT, the total $\mathrm{N}$ in the shoot of plants treated with N-free NS and inoculated with the strain CIAT 899 was even higher $(3.10 \%$ vs. $2.73 \%$ in dry weight) than in non-inoculated plants treated with standard $\mathrm{N}$ levels $(100 \%$ of the standard recommendation). These results are in agreement with those reported by Hungria et al. (2000), who found similar total $\mathrm{N}$ levels in $P$. vulgaris plants inoculated with $R$. tropici strain CIAT899 and supplied with
$\mathrm{N}$-free NS with those measured in plants supplied with mineral $\mathrm{N}$ in a greenhouse trial. On the other hand, the shoots of plants fed with $\mathrm{N}$-free NS in the present study contained less $\mathrm{N}$ (17.4 $\mathrm{mg} \cdot \mathrm{g}^{-1}$ dry weight, average calculated across all samplings dates) than those fed with SNS when the former were inoculated with the commercial inoculants. However, this is reasonable given the poor root nodulation and the results of PCR analysis, which revealed the absence of $\mathrm{N}_{2}$ fixing microorganisms in the roots of plants inoculated with the commercial mix.

Yield and biomass production. Despite the sufficiently high $\mathrm{N}$ levels in the shoot of plants inoculated with the strain CIAT899 and fed with an N-free NS, at least from Day 45 after transplanting and onward, both the total biomass production (Fig. 3) and the green pod yield (Table 2) were appreciably lower than in the non-inoculated plants supplied with $100 \% \mathrm{~N}$. However, the similar shoot $\mathrm{N}$ concentrations indicate that the appreciable suppression of growth (221.43 g/plant vs. $32.31 \mathrm{~g} /$ plant 90 DAS) and pod yield (107.1 g/plant vs. $18.51 \mathrm{~g} /$ plant) in $P$. vulgaris plants inoculated with $R$. tropici in comparison with the control was not associated with deficient tissue $\mathrm{N}$ levels throughout the cropping period, despite their cultivation on an inert medium lacking any $\mathrm{N}$ and the continuous supply of $\mathrm{N}$-free NS. This was surprising and a likely explanation is that the plant biomass was restricted as a result of a shortage of $\mathrm{N}$ in the early growth stage of common bean, before $R$. tropici bacteroids were developed enough to be capable of providing sufficient $\mathrm{N}$ to the plants. The occurrence of a severe $\mathrm{N}$ shortage in the plants treated with $\mathrm{N}$-free NS despite inoculation with $R$. tropici CIAT899 during the first 3 to 5 weeks after inoculation is reasonable. Indeed, it is well known that a period of 3 to 5 weeks is needed between infection with $\mathrm{N}_{2}$-fixing microorganisms and the onset of $\mathrm{N}_{2}$ fixation, and during this period, the plant has to provide $\mathrm{N}$ both to itself and to the bacteroids (Kucey, 1989; Marschner, 1995).

Tissue mineral composition. The supply of $\mathrm{N}$-free NS restricted appreciably the $\mathrm{K}^{+}$, $\mathrm{Mg}^{2+}$, and $\mathrm{Zn}^{2+}$ levels in the aboveground plant biomass, regardless of inoculation treatment. Only on the third sampling date did the shoot $\mathrm{Mg}^{2+}$ concentration in the plants treated with $\mathrm{N}$-free NS and inoculated with the commercial mix $\left(3.87 \mathrm{mg} \cdot \mathrm{g}^{-1}\right)$ tend to approach that of the control plants (4.41 mg. $\mathrm{g}^{-1}$ ). $\mathrm{K}^{+}$and $\mathrm{Mg}^{2+}$, together with $\mathrm{Ca}^{2+}$ (which was not measured), constitute the three major nutrient cations for plants. Both $\mathrm{K}^{+}$and $\mathrm{Mg}^{2+}$ are actively 
absorbed through dual transport mechanisms so as to electrochemically balance the cytosol (Marschner, 1995). On the other hand, $\mathrm{NO}_{3}{ }^{-}$is the major nutrient anion, which accounts for $\approx 70 \%$ to $80 \%$ of the total ion uptake in higher plants (Van Beusichem et al., 1988). Plants supplied with N-free NS cannot take up any $\mathrm{NO}_{3}^{-}$and thus the total anion uptake is accordingly suppressed. The low $\mathrm{NO}_{3}{ }^{-}$availability in the roots may signal a marked suppression of $\mathrm{K}^{+}$and $\mathrm{Mg}^{2+}$ uptake through the active transport mechanisms localized in the root cells (Mengel and Kirkby, 2001) to maintain electrochemical balance in the cytosol. As reported by Raab and Terry (1994), low $\mathrm{NO}_{3}{ }^{-}$concentrations in the roots restrict cation uptake because $\mathrm{NO}_{3}{ }^{-}$anions are needed to counterbalance cations in the xylem. In legumes, $\mathrm{N}_{2}$ fixation results in a net release of $\mathrm{H}^{+}$ions (Bolan et al., 1991) and this may entail a further restriction of $\mathrm{K}^{+}$and $\mathrm{Mg}^{2+}$ uptake by roots in the absence of $\mathrm{NO}_{3}{ }^{-}$in the root zone aiming at maintaining the electrochemical balance in the root cells. The $\mathrm{K}$ levels in the shoot of bean plants treated with $\mathrm{N}$-free NS were markedly lower (15.2 $\mathrm{mg} \cdot \mathrm{g}^{-1}$, average calculated across all sampling dates) than the lower critical level suggested by Mills and Jones (1996), in contrast to those of $\mathrm{Mg}$ (4.06 mg.g ${ }^{-1}$, average calculated across all samplings dates), which were still within the sufficiency range. Also the shoot $\mathrm{Zn}$ levels (28.09 $\mathrm{mg} \cdot \mathrm{g}^{-1}$, average calculated across all

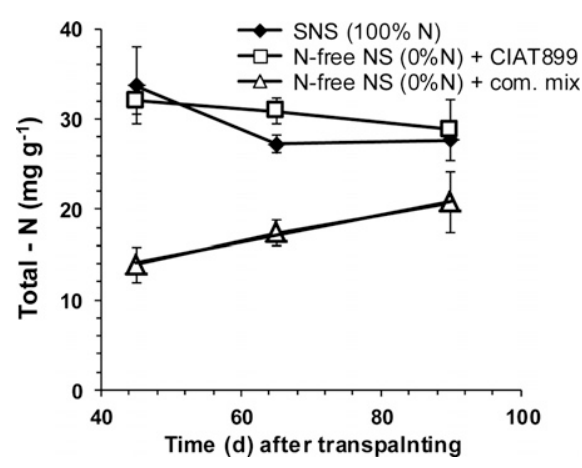

Fig. 3. Total nitrogen $(\mathrm{N})$ concentrations in the aboveground dry biomass in a hydroponic crop of common bean inoculated either with $R$. tropici CIAT 899 or with a commercial mix containing various rhizobia and Azotobacter sp. strains or non-inoculated. The inoculated plants were supplied with $\mathrm{N}$-free nutrient solution, whereas the non-inoculated plants were fed with a nutrient solution containing $100 \%$ of the standard recommended $\mathrm{N}$ level. SNS = standard nutrient solution. Vertical bars depict \pm $\operatorname{SES}(n=4)$. samplings dates) were clearly below the critical level of sufficiency in the bean plants treated with $\mathrm{N}$-free NS. The supply of $\mathrm{N}$-free NS reduced significantly the shoot $\mathrm{P}$ concentration 65 DAT, irrespective of inoculation treatment (Fig. 4). This is attributed to the increased number of nodules at this growth stage in both inoculated treatments, because many studies have shown that nodules are strong sinks for P (Drevon and Hartwig, 1997; Kleinert et al., 2014). Indeed, as reported by Vadez et al. (1996), the P concentration in nodules formed by $\mathrm{N}_{2}$-fixing bacteria is 3 -fold higher than in plant tissues.

As stated by O'Hara et al. (1988), nutrient deficiencies constitute a major constraint limiting biological $\mathrm{N}_{2}$ fixation and yield in
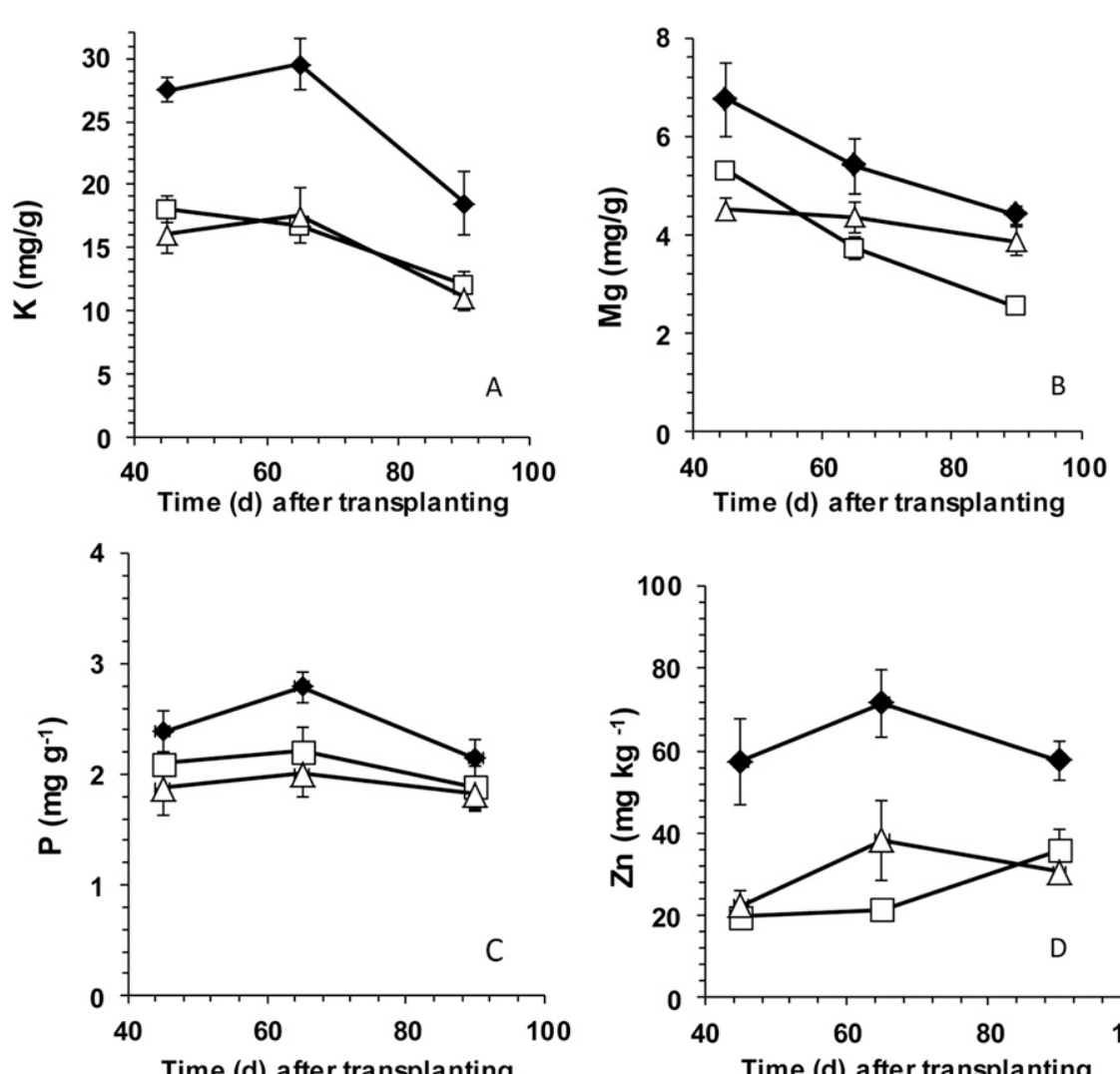

legume crops. Thus, a partial involvement of $\mathrm{K}$ and/or $\mathrm{Zn}$ deficiency in the appreciable suppression of growth and pod yield in $P$. vulgaris plants treated with $\mathrm{N}$-free $\mathrm{NS}$ is likely. Nevertheless, based on the results of the present study, it is not possible to estimate the relative contribution of $\mathrm{N}$ deficiency during the early developmental stage vs. K and $\mathrm{Zn}$ deficiencies to growth and yield suppression in bean plants treated with $\mathrm{N}$-free NS and inoculated with $R$. tropici CIAT899.

Legume crops may need to be inoculated only when they are grown in regions outside their centers of diversity or where they have not traditionally been grown or have not been grown for a number of years (Brockwell et al.,

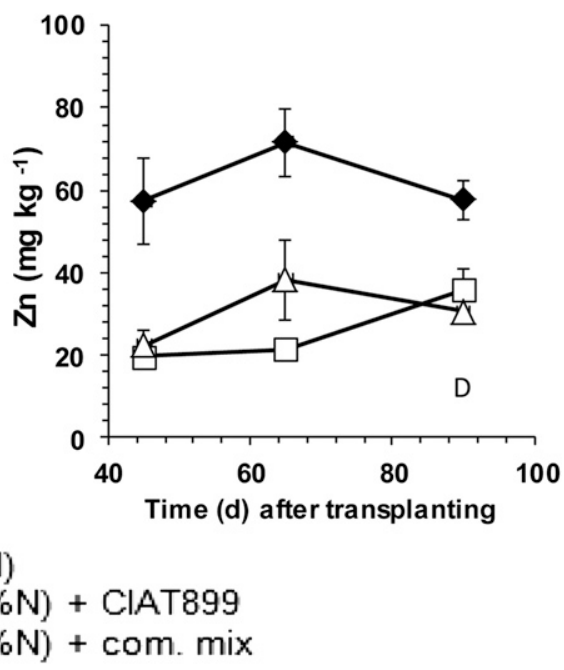

Fig. 4. Potassium, magnesium, phosphorus, and zinc concentrations in the aboveground dry biomass of hydroponically grown common bean inoculated either with $R$. tropici CIAT 899 or with a commercial mix containing various rhizobia and Azotobacter sp. strains or non-inoculated. The inoculated plants were supplied with nitrogen $(\mathrm{N})$-free nutrient solution, whereas the non-inoculated plants were fed with a nutrient solution containing $100 \%$ of the standard recommended $\mathrm{N}$ level. SNS $=$ standard nutrient solution. Vertical bars depict $\pm \operatorname{SES}(n=4)$.

Table 2. Fresh pod yield and yield components, dry pod yield, and dry matter content (DMC) in a hydroponic crop of common bean inoculated either with R. tropici CIAT 899 or with a commercial mix containing various rhizobia and Azotobacter sp. strains or non-inoculated. ${ }^{\mathrm{z}}$

\begin{tabular}{|c|c|c|c|c|c|}
\hline Treatment & Pod number per plant & Fresh pod wt (g/plant) & Dry pod wt (g/plant) & Mean pod wt (g) & DMC (\%) \\
\hline $100 \% \mathrm{~N}$ & $11.5 \pm 0.5 \mathrm{a}$ & $107.1 \pm 7.5 \mathrm{a}$ & $8.6 \pm 0.81 \mathrm{a}$ & $9.3 \pm 0.55 \mathrm{a}$ & $8.01 \pm 0.2 b$ \\
\hline $0 \% \mathrm{~N}+R$. tropici & $3.1 \pm 0.1 \mathrm{~b}$ & $18.5 \pm 1.1 \mathrm{~b}$ & $1.7 \pm 0.13 b$ & $6.5 \pm 0.54 b$ & $9.04 \pm 0.3 \mathrm{a}$ \\
\hline $0 \% \mathrm{~N}+$ commercial mixture & $1.4 \pm 0.4 \mathrm{c}$ & $\begin{array}{l}3.8 \pm 0.2 \mathrm{c} \\
\text { Statistical significance }\end{array}$ & $0.3 \pm 0.05 \mathrm{c}$ & $2.3 \pm 0.37 \mathrm{c}$ & $7.53 \pm 0.2 b$ \\
\hline & $* * *$ & $* * *$ & $* * *$ & $* * *$ & ** \\
\hline
\end{tabular}

${ }^{\mathrm{z}}$ The inoculated plants were supplied with nitrogen $(\mathrm{N})$-free nutrient solution, whereas the non-inoculated plants were fed with a nutrient solution containing $100 \%$ of the standard recommended $N$ level. Significant differences at $P \leq 1 \%$ and $0.1 \%$, are denoted by $* *$ and $* * *$, respectively. 
1995). Substrates on which common bean may be grown for the production of green pods do not host naturally efficient rhizobia strains for $\mathrm{N}_{2}$ fixation. Thus, inoculation with efficient rhizobia strains for bean such as $R$. tropici CIAT899 is essential for the reduction of external $\mathrm{N}$ supply in inorganic form through biological $\mathrm{N}_{2}$ fixation. The results of the present study showed that inoculation with $R$. tropici CIAT899 results in extensive nodulation and adequate biological $\mathrm{N}_{2}$ fixation for maintenance of sufficient $\mathrm{N}$ levels in the plant tissues. As a general rule, common bean plants fix $\approx 15 \mathrm{~kg}$ shoot $\mathrm{N}$ for every ton of shoot dry matter accumulated (Unkovich et al., 2008). As reported by the same authors, the true value of $\mathrm{N}_{2}$ fixation can be known only under defined conditions when the organism in question either fixes no $\mathrm{N}_{2}$ or is totally dependent on $\mathrm{N}_{2}$ fixation for growth. Thus, plants growing with their competent $\mathrm{N}_{2}$-fixing bacteria in the absence of any other plant-available sources of $\mathrm{N}$ will derive all $\mathrm{N}(100 \%)$ from $\mathrm{N}_{2}$ fixation, except for a very small amount originating from the sown seed (Unkovich et al., 2008). In the present study, the plants inoculated with $R$. tropici CIAT899 did not receive any external $\mathrm{N}$ except for that of the seed. Thus, the total $\mathrm{N}$ concentration measured in the shoots of these plants $\left(30 \mathrm{mg} \cdot \mathrm{kg}^{-1}\right.$, i.e., $30 \mathrm{~g}$ per ton shoot dry weight) can be considered net $\mathrm{N}_{2}$ fixation. This amount is three times as high as that reported by Unkovich et al. (2008) indicating that $\mathrm{N}_{2}$ fixation in bean crops grown on substrates is highly efficient after inoculation with $R$. tropici CIAT899.

\section{Conclusion}

Inoculation of bean plants with $R$. tropici CIAT899 results in efficient nodulation and biological $\mathrm{N}_{2}$ fixation in bean crops grown on $\mathrm{N}$-free substrates when $\mathrm{N}$-starved nutrient solution is supplied. However, this is the case only after the first 3 to 5 weeks of growth. During the early developmental period, the availability of sufficient mineral $\mathrm{N}$ in the root environment is critical, because the bean/ Rhizobium symbiosis is not able to supply adequate amounts of $\mathrm{N}$ for plant growth. In the present study, inoculation with $R$. tropici CIAT899 was combined with the supply of $\mathrm{N}$-free NS even during the early growth stages and thus both vegetative growth and yield were severely restricted. In addition, the absence of any $\mathrm{NO}_{3}{ }^{-}$supply restricted the uptake of $\mathrm{K}$ and other nutrient cations. Based on these results it is concluded that an adequate supply of mineral $\mathrm{N}$ during the first 3 to 5 weeks of cropping and a continuous supply of some $\mathrm{NO}_{3}^{-}$(but less than in noninoculated crops) throughout the cropping period are essential practices to benefit from rhizobia inoculation in common bean crops grown hydroponically.

\section{Literature Cited}

Altschul, S.F., T.L. Madden, A.A. Schaffer, J. Zhang, Z. Zhang, W. Miller, and D.J. Lipman.
1997. Gapped BLAST and PSI-BLAST: A new generation of protein database search programs. Nucleic Acids Res. 25:3389-3402.

Beringer, J. 1974. R factor transfer in Rhizobium leguminosarum. J. Gen. Microbiol. 84:188198.

Bolan, N.S., M.J. Hedley, and R.E. White. 1991 Processes of soil acidification during nitrogen cycling with emphasis on legume based pastures. Plant Soil 134:53-63.

Brockwell, J., P.J. Bottomley, and J.E. Thies. 1995. Manipulation of rhizobia microflora for improving legume productivity and soil fertility: A critical assessment. Plant Soil 174:143-180.

Catroux, G., A. Hartmann, and C. Revellin. 2001. Trends in rhizobial inoculant production and use. Plant Soil 230:21-30.

Drevon, J.J. and U.A. Hartwig. 1997. Phosphorus deficiency increases the argon-induced decline of nodule nitrogenase activity in soybean and alfalfa. Planta 200:463-469.

Eaton, A.D., L.S. Clesceri, and A.E. Greenberg. 1995. Standard methods for the examination of water and wastewater. 19th ed. American Public Health Association, Washington, DC.

Gan, Y., I. Stulen, H. van Keulen, and P.J.C. Kuiper. 2004. Low concentrations of nitrate and ammonium stimulate nodulation and $\mathrm{N}_{2}$ fixation while inhibiting specific nodulation (nodule DW $\mathrm{g}^{-1}$ root dry weight) and specific $\mathrm{N}_{2}$ fixation $\left(\mathrm{N}_{2}\right.$ fixed $\mathrm{g}^{-1}$ root dry weight) in soybean. Plant Soil 258:281-292.

Graham, P.H. 1981. Some problems of nodulation and symbiotic nitrogen fixation in Phaseolus vulgaris L.: A review. Field Crops Res. 4:93112.

Hardarson, G. 1993. Methods for enhancing symbiotic nitrogen fixation. Plant Soil 152:1-17.

Hungria, M., D.S. Andrade, L.M.O. Chueire, A. Probanza, F.J. Guttierrez-Manero, and M. Megías. 2000. Isolation and characterization of new efficient and competitive bean (Phaseolus vulgaris L.) rhizobia from Brazil. Soil Biol. Biochem. 32:1515-1528.

Hungria, M., R.C. Jos, and I.C. Mendes. 2003. Benefits of inoculation of the common bean (Phaseolus vulgaris) crop with efficient and competitive Rhizobium tropici strains. Biol. Fertil. Soils 39:88-93.

Jebara, M., J.-J. Drevon, and M.E. Aouani. 2001. Effects of hydroponic culture system and $\mathrm{NaCl}$ on interactions between common bean lines and native rhizobia from Tunisian soils. Agronomie 21:601-605.

Jiang, H., H. Dong, G. Zhang, B. Yu, L.R. Chapman, and M.W. Fileds. 2006. Microbial diversity in water and sediment of Lake Chaka, an athalassohaline lake in northwestern China. Appl. Environ. Microbiol. 72:3832-3845.

Kleinert, A., M. Venter, J. Kossmann, and A. Valentine. 2014. The reallocation of carbon in $\mathrm{P}$ deficient lupins affects biological nitrogen fixation. J. Plant Physiol. 171:1619-1624.

Kucey, R.M.N. 1989. The influence of rate and time of mineral $\mathrm{N}$ application on yield and $\mathrm{N}_{2}$ fixation by field bean. Can. J. Plant Sci. 69:427-436

Lane, D.J. 1991. 16S/23S rRNA sequencing, p. 125 175. In: Stackebrandt, E. and M. Goodfelow (eds.). Nucleic acid techniques in bacterial systematic. Wiley, Chichester, UK.

Lane, D.J., B. Pace, G.J. Olsen, D.A. Stahl, M.L. Sogin, and N.R. Pace. 1985. Rapid determination of 165 ribosomal RNA sequences for phylogenetic analyses. Proc. Natl. Acad. Sci. USA 82:6955-6959.

Li, Y.Y., C.B. Yu, X. Cheng, C.J. Li, J.H. Sun, F.S Zhang, H. Lambers, and L. Li. 2009. Intercropping alleviates the inhibitory effect of $\mathrm{N}$ fertilization on nodulation and symbiotic $\mathrm{N}_{2}$ fixation of faba bean. Plant Soil 323:295-308.

Marschner, H. 1995. Mineral nutrition of higher plants. 2nd ed. Academic Press, London, UK.

Martinez-Romero, E., L. Segovia, F.M. Mercante, A.A. Franco, P. Graham, and M.A. Pardo. 1991. Rhizobium tropici, a novel species nodulating Phaseolus vulgaris L. beans and Leucaena sp. trees. Intern. J. Syst. Bacteriol 41: 417-426.

Mengel, K. and E.A. Kirkby. 2001. Principles of plant nutrition. 5th ed. Kluwer Academic Publishers, Dordrecht, The Netherlands.

Mhamdi, R., M. Mrabet, G. Laguerre, R. Tiwari, and M.E. Aouani. 2005. Colonization of Phaseolus vulgaris nodules by Agrobacterium-like strains. Can. J. Microbiol. 51:105-111.

Mills, H.A. and J.B. Jones, Jr. 1996. Plant analysis handbook II. MicroMacro Publishing Inc., Athens, GA.

Mostasso, L., B.G. Dias, M.A.T. Vargas, and M. Hungria. 2002. Selection of bean (Phaseolus vulgaris L.) rhizobial strains for the Brazilian Cerrados. Field Crops Res. 73:121-132.

O’Hara, G.W., N. Boonkerd, and M.J. Dilworth. 1988. Mineral constraints to nitrogen fixation. Plant Soil 108:93-110.

Postma, J., E. van Os, and P.J.M. Bonants. 2008 Pathogen detection and management strategies in soilless plant growing systems, p. 425-457. In: Raviv, M. and H.J. Lieth (eds.). Soilless culture: Theory and practice. Elsevier, Amsterdam, The Netherlands.

Raab, T.K. and N. Terry. 1994. Nitrogen-source regulation of growth and photosynthesis in Beta vulgaris L. Plant Physiol. 105:1159-1166.

Remans, R., L. Ramaekers, S. Schelkens, G. Hernandez, A. Garcia, J.L. Reyes, N. Mendez, V. Toscano, M. Mulling, L. Galvez, and J. Vanderleyden. 2008. Effect of RhizobiumAzospirillum coinoculation on nitrogen fixation and yield of two contrasting Phaseolus vulgaris L. genotypes cultivated across different environments in Cuba. Plant Soil 312:25-37.

Rodelas, B., J.M. González-López, V. MartínezToledo, C. Pozo, and V. Salmerón. 1999. Influence of Rhizobium/Azotobacter and Rhizobium/Azospirillum combined inoculation on mineral composition of faba bean (Vicia faba L.). Biol. Fertil. Soils 29:165-169.

Savvas, D., G.P. Gianquinto, Y. Tüzel, and N. Gruda. 2013. Soilless culture, p. 303-354. In: Good agricultural practices for greenhouse vegetable crops. Principles for Mediterranean climate areas. FAO, Plant Production and Protection Paper 217, Rome, Italy. <http://www.fao.org/ docrep/018/i3284e/i3284e.pdf $>$.

Segovia, L., D. Pinero, R. Palacios, and E. Martinez-Romero. 1991. Genetic structure of a soil population of nonsymbiotic Rhizobium leguminosarum. Appl. Environ. Microbiol. 57:426-433.

Singleton, P.W. and J.W. Tavares. 1986. Inoculation response of legumes in relation to the number and effectiveness of indigenous Rhizobium populations. Appl. Environ. Microbiol. 51:10131018 .

Stephens, J.H.G. and H.M. Rask. 2000. Inoculant production and formulation. Field Crops Res. 65:249-258.

Thies, J.E., P.W. Singleton, and B.B. Bohlool. 1991. Influence of the size of indigenous rhizobial populations on establishment and symbiotic performance of introduced rhizobia on field-grown legumes. Appl. Environ. Microbiol. 57:19-28.

Unkovich, M., D. Herridge, M. Peoples, G. Cadisch, R. Boddey, K. Giller, B. Alves, and 
P. Chalk. 2008. Measuring plant-associated nitrogen fixation in agricultural systems. ACIAR Monograph No. 136, Canberra, Australia.

Vadez, V., F. Rodier, H. Payre, and J.J. Drevon. 1996. Nodule conductance to $\mathrm{O}_{2}$ and nitrogenaselinked respiration in bean genotypes varying in the tolerance of $\mathrm{N}_{2}$ fixation to $\mathrm{P}$ deficiency. Plant Physiol. Biochem. 34:871-878.
Van Beusichem, M.L., E.A. Kirkby, and R. Baas. 1988. Influence of nitrate and ammonium nutrition on the uptake, assimilation, and distribution of nutrients in Ricinus communis. Plant Physiol. 86:914-921.

Vincent, J.M. 1970. A manual for the practical study of the root-nodule bacteria. A manual for the practical study of the root-nodule bacteria.
IBP Handbk 15. Blackwell Scientific Publications, Oxford and Edinburgh, UK.

Zaman-Allah, M., B. Sifi, B. L'Taief, M.H. El Aouni, and J.J. Drevon. 2007. Rhizobial inoculation and $\mathrm{P}$ fertilization response in common bean (Phaseolus vulgaris) under glasshouse and field conditions. Exp. Agr. 43:67-77. 